\author{
Sławomir Dorocki, Agnieszka Świętek \\ Uniwersytet Pedagogiczny \\ im. Komisji Edukacji Narodowej \\ w Krakowie
}

\title{
Działania wybranych instytucji publicznych na rzecz wsparcia przedsiębiorczości w dobie kryzysu gospodarczego w Polsce
}

\author{
The functioning of selected public institutions for supporting entrepreneurship \\ during an economic crisis in Poland
}

\begin{abstract}
Streszczenie
Najbardziej wyraźnym i dotkliwym efektem współczesnego kryzysu gospodarczego dla polskiego społeczeństwa jest zwiększające się bezrobocie, które pociąga za sobą negatywne skutki nie tylko gospodarcze, lecz również społeczne. Jednym ze sposobów skutecznej walki z recesją gospodarczą i spadkiem zatrudnienia jest pobudzanie i wspieranie przedsiębiorczości. Rozwój przedsiębiorczości wydaje się najlepszym narzędziem do walki z bezrobociem, gdyż nie skupia się na łagodzeniu doraźnych skutków związanych z utratą pracy, lecz koncentruje się na walce z jego przyczyną. Przedsiębiorczość, w dobie kryzysu, powinna działać w trzech obszarach gospodarki. Są to: promowanie postawy przedsiębiorczej wśród ludzi młodych, rozwój innowacyjności w przedsiębiorstwach (ucieczka „do przodu”) oraz stymulowanie samozatrudnienia.

W artykule autorzy koncentrują się na ostatnim z wymienionych działań mających na celu zmniejszenie stopy bezrobocia w Polsce, tj. pobudzaniu przedsiębiorczości przez zachęcanie do podejmowania samodzielnej działalności gospodarczej. W analizie przedstawione zostały działania wybranych instytucji publicznych wspierających osoby chcące założyć i prowadzić własną działalność gospodarczą. Przedstawiając działalność poszczególnych urzędów, autorzy wskazują możliwości, z których mogą skorzystać potencjalni przedsiębiorcy. Wykazane zostały m.in. rodzaje udzielanego wsparcia, wielkość i ilość środków przekazywanych na rozpoczęcie działalności oraz skuteczność owej pomocy, również w ocenie samych przedsiębiorców.
\end{abstract}

\begin{abstract}
The most distinct and painful effect of the present economic crisis for the Polish society is the increasing unemployment, which causes negative consequences, not only economic, but above all - social. One of the ways to fight of economic recession and the decline in employment is encouraging and supporting entrepreneurship. Development of entrepreneurship seems to be the best way to fight unemployment, because it does not focus on mitigating its effects, but concentrates on defeating its direct cause. Entrepreneurship in times of crisis should concentrate on three areas of the economy: promotion of entrepreneurial attitudes among young people, development of innovation in enterprises (escape "forward") and stimulation of self-employment.

In this article, the authors focus on that last way of reducing the rate of unemployment in Poland stimulation of entrepreneurship, so as to create new businesses. In the analysis, the actions of selected public institutions, which assist individuals wishing to set up and run their own business, are presented. By outlining the activities of various institutions, authors demonstrate the possibilities which potential entrepreneurs can take advantage of. Among other types of support, the article de-
\end{abstract}


scribes the size and quantity of grants for setting up a business, and the effectiveness of this form of assistance, also in the opinion of new entrepreneurs.

Słowa kluczowe: kryzys gospodarczy; PARP; publiczne wsparcie przedsiębiorczości; urzędy pracy

Key words: economic crisis; PARP; public support for entrepreneurship; employment agency

\section{Wprowadzenie}

Wszechobecne słowo kryzys zdążyło nam się już osłuchać, by nie powiedzieć - znudzić. Już cztery lata minęły od symbolicznego rozpoczęcia kryzysu 15 września 2008 r., kiedy to nastąpił krach na giełdzie papierów wartościowych na Wall Street. Katalizatorem kryzysu finansowego było ogłoszenie bankructwa przez Lehman Brothers, czwarty pod względem wielkości amerykański bank inwestycyjny. Dla rynków finansowych, a dalej - gospodarek poszczególnych krajów - pociągnęło to za sobą konsekwencje o skali światowej. Od tamtej pory informacje o kryzysie, jego przyczynach, przebiegu, konsekwencjach, politycznych szczytach, ekonomicznych prognozach i skutkach towarzyszą nam stale, głównie za pośrednictwem poruszających ten temat mediów. Czy chcemy jednak tego, czy nie, zdarzenia makroekonomiczne mają w dobie globalnej gospodarki bezpośredni wpływ na nasze codzienne życie. Abstrahując od przewidywań i nie wdając się w dyskusję o tym, kiedy kryzys w Polsce się skończy, czy może jeszcze w ogóle się nie zaczął, autorzy skupili się w niniejszym artykule na jego ważnym i niezaprzeczalnym efekcie, jakim jest rosnące bezrobocie oraz przedsiębiorczości jako orężu walki z tym problemem.

Przedmiotem badań autorów i jednocześnie niniejszej pracy są działania wybranych instytucji publicznych na rzecz wsparcia przedsiębiorczości w dobie kryzysu gospodarczego w Polsce. Szczegółowym celem podjętej pracy było określenie zakresu i ocena działania instytucji państwowych w postaci urzędów pracy oraz Polskiej Agencji Rozwoju Przedsiębiorczości (PARP) w zakresie wsparcia udzielanego osobom zakładającym działalność gospodarczą. Badania obejmowały analizę przygotowywanych przez wojewódzkie urzędy pracy Regionalnych planów na rzecz zatrudnienia, analizę danych statystycznych zgromadzonych w raporcie Ministerstwa Pracy i Polityki Socjalnej (MPiPS), analizę i ocenę działań tych instytucji w zakresie wsparcia przedsiębiorczości oraz studium przypadku Grodzkiego Urzędu Pracy w Krakowie, które posłużyło do weryfikacji teoretycznych założeń zawartych w planach działania urzędu. W analizach brano pod uwagę najbardziej aktualne, dostępne dane. Jedynie część z nich obejmuje wyłącznie okres 2008-2010, gdyż takie dane zawarto w cennym dla autorów raporcie MPiPS Badanie ogólnopolskie nt. stosowanej formy aktywizacji zawodowej bezrobotnych, jaka jest przyznawanie środków Funduszu Pracy na podjęcie działalności gospodarczej, ze względu na to, że rok 2008 był początkową datą kryzysu finansowego.

\section{Wspieranie przedsiębiorczości w walce z rosnącą stopą bezrobocia}

Zwiększająca się stopa bezrobocia jest niezaprzeczalnie najbardziej widocznym i dotkliwym efektem kryzysu gospodarczego dla każdego społeczeństwa (Batorska, 2005; Dorocki, 2011). Dzieje się tak, gdyż wywołuje ona negatywne skutki nie tylko ekonomiczne, ale nade wszystko - społeczne. Pierwszą konsekwencją utraty pracy dla pracownika i jego rodziny jest pogorszenie standardu życia. W parze z nim następuje pogorszenie stanu psychicznego bezrobotnego, o bardzo różnym nasileniu, uzależnionym od licznych czynników: sytuacji rodzinnej, materialnej czy odporności psychicznej. W skrajnych przypadkach utrata pracy i trudności ze znalezieniem nowego zatrudnienia są przyczyną depresji, nałogów, a nawet problemów z prawem. Pogorszenie stanu psychicznego prowadzić może także do różnych form izolacji 
społecznej. Osoby bezrobotne, z racji ograniczonych środków i obniżonego poczucia własnej wartości, ograniczają uczestnictwo w życiu społecznym, kulturalnym czy politycznym lub w ogóle go nie podejmują. Bezrobocie ma zatem szereg poważnych negatywnych konsekwencji społecznych.

W latach 1990-2012 (ostatnie dane za wrzesień 2012 r.) stopa bezrobocia w Polsce ulegała wahaniom od 6,1\% w roku 1990 do maksymalnego poziomu 20\% w latach 2003 i 2004. Od 2004 r. bezrobocie w Polsce spadało aż do roku 2008, kiedy to osiągnęło najniższy od czasu „uwolnienia” polskiej gospodarki poziom 9,5\% (ryc. 1). Od roku 2008, co pokrywa się z oficjalnie przyjmowaną datą rozpoczęcia kryzysu, stopa bezrobocia w Polsce nie gwałtownie, ale jednak wzrosła. W latach 2010 i 2011, tak jak i w ostatnim badanym miesiącu (wrzesień 2012 r.) wynosiła ona $12,5 \%$.

Zdaniem autorów, najlepszym narzędziem do walki z bezrobociem, w szczególności w dobie kryzysu, jest wspieranie rozwoju przedsiębiorczości. Jest tak, ponieważ rozwój przedsiębiorczości nie tylko powoduje łagodzenie skutków bezrobocia, jak czynią to doraźne działania wspierające, w szczególności te oparte na jednorazowych daninach państwowych, lecz na walce z jego przyczyną - utratą pracy. Dodatkowym czynnikiem przemawiającym za pobudzeniem aktywności gospodarczej są kłopoty finansowe państwa, które w okresie kryzysu są tym bardziej odczuwalne i wpływają na obniżenie możliwości interwencyjnych władz publicznych.

Wspieranie przedsiębiorczości zdaniem autorów, w szczególności w okresie trudności gospodarczych, powinno skupiać się na trzech elementach:

- promowaniu, szczególnie wśród ludzi młodych, postawy przedsiębiorczej,

- rozwoju przedsiębiorstw na bardzo różnych polach (,ucieczce do przodu”),

- dążeniu do zakładania własnej działalności gospodarczej (szczególnie przez osoby młode, bezrobotne) w celu uzyskania samozatrudnienia i tworzenia nowych miejsc pracy.

Promowanie postawy przedsiębiorczej wśród ludzi młodych winno rozpoczynać się jak najwcześniej. Jak wynika z badań nad szkolnymi programami nauczania z zakresu przedsiębiorczości w latach 2009-2012, prowadzonymi w wybranych regionach Polski, Niemiec oraz Szkocji, w wielu regionach wskazanych trzech krajów nauczanie przedsiębiorczości rozpoczyna się dopiero w szkołach średnich. Przedsiębiorczość jako samodzielny przedmiot szkolny nie występuje na etapie edukacyjnym gimnazjum (i jego odpowiedników w innych krajach), a jedynie wybrane treści związane z kształtowaniem wiedzy i postaw przedsiębiorczych pojawiają się na innych zajęciach, co zdaniem autorów badań powinno ulec zmianie. Jak dowodzą

Ryc. 1. Zmiany poziomu stopy bezrobocia w Polsce w latach 1990-2012

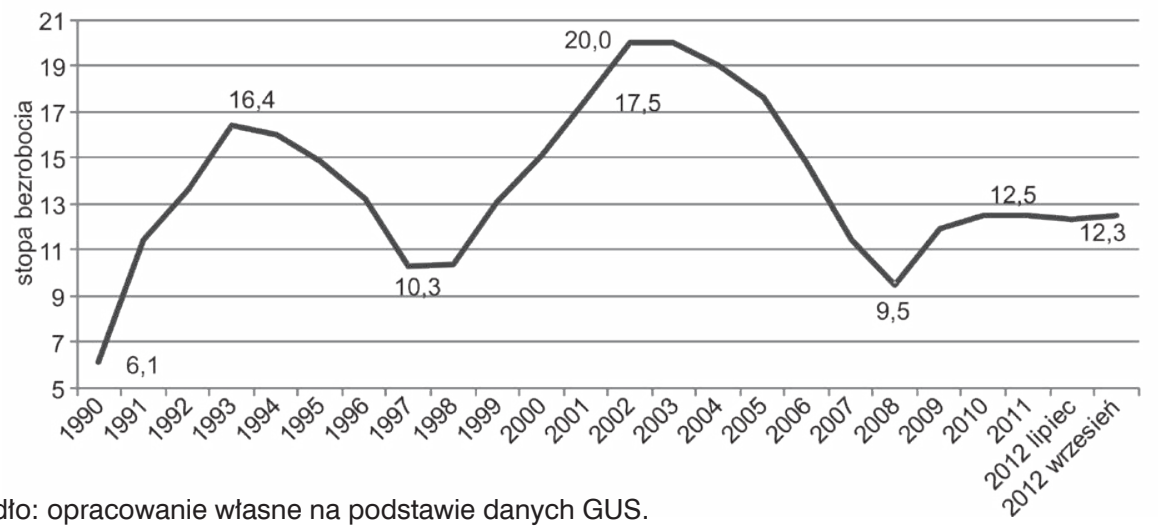

Źródło: opracowanie własne na podstawie danych GUS. 
przytoczone badania, zróżnicowany jest również zakres i obszar podejmowanej tematyki z przedsiębiorczości - w Szkocji tematyka zajęć skupia się na możliwościach znalezienia zatrudnienia lokalnie, $\mathrm{z}$ uwzględnieniem miejscowej struktury zatrudniania, a w Niemczech tematyka zajęć obejmuje szersze spojrzenie na gospodarkę, otoczenie rynkowe i uwzględnia zbiorowe kompetencje (Berger i in., 2012). W Polsce zagadnienia dotyczące przedsiębiorczości pojawiają się w gimnazjum w ramach przedmiotu wiedza o społeczeństwie, a następnie w szkole średniej na lekcjach przedmiotu podstawy przedsiębiorczości. Od bieżącego roku szkolnego dodatkowo tematyka ta będzie realizowana na zupełnie nowym przedmiocie ekonomia w praktyce.

Kształcenie w zakresie przedsiębiorczości, pomimo wskazywanych wad i potrzeby zmian, podlega jednak pozytywnym zmianom. To bardzo istotne, gdyż wybory dokonywane przez uczniów szkół średnich, dotyczące dalszej ścieżki kształcenia, powinny uwzględniać nie tylko ich zainteresowania, lecz także przyszłość na rynku pracy. Świadome planowanie swojego rozwoju zawodowego i wybór dalszego kierunku kształcenia na tak powszechnie wybieranych dziś studiach wyższych powinny być jednym z zadań przedmiotu podstawy przedsiębiorczości. W pewnym zakresie zadanie to już wydaje się być po części realizowane, gdyż młodzi ludzie, wybierając kierunek kształcenia, coraz częściej dokonują wyborów świadomych, uwzględniających przyszłość zawodową. Przykładem niech będą choćby wyniki badań przeprowadzonych w 2011 r. wśród 1347 studentów geografii 12 polskich uczelni państwowych. Badani studenci, zapytani o to, gdzie planują poszukiwać pracy po studiach, w zdecydowanej większości wybierali miejsca, których zdobycie związane jest z ukończonym kierunkiem studiów. Zadeklarowali oni plan poszukiwania pracy w: administracji państwowej i samorządowej (12,7\%), biurach planowania przestrzennego $(11,4 \%)$, szkolnictwie $(10,9 \%)$, przedsiębiorstwach geodezyjnych i kartograficznych (10,1\%) lub w założonej przez siebie działalności (9,5\%) (Piróg, 2012). Warto przy tym zaznaczyć, że cenna z punktu widzenia rynku pracy byłaby reorientacja celów współczesnych szkół wyższych w zakresie kształcenia akademickiego. Sytuacja społeczno-gospodarcza wymusza na nich zaprzestanie koncentrowania się wyłącznie na kształceniu elity intelektualnej (Piróg, 2012) i uwzględnianie w profilach kształcenia również przygotowania do wykonywania konkretnych zawodów lub prowadzenia działalności gospodarczej, z czym wiele uczelni nie może się jednak pogodzić.

Drugim wskazanym przez autorów zadaniem instytucji wspierających przedsiębiorczość w dobie kryzysu gospodarczego jest pomoc przedsiębiorstwom w ,ucieczce do przodu”, rozumianej przez autorów jako ucieczka przed konsekwencjami kryzysu dzięki rozwojowi przedsiębiorstwa (Dąbrowski, 2010). Rozwój przedsiębiorstw w różnych zakresach, jak choćby produktowym czy organizacyjnym, sprawia, że stają się one bardziej konkurencyjne na rynku, przez co mają większą szansę na przetrwanie niekorzystnej koniunktury (Zioło, 2007). Wsparcie przedsiębiorstw powinno zatem nie skupiać się na pomocy w zakładaniu działalności, lecz na wsparciu ich rozwoju, biorąc pod uwagę zasadę: „Kto nie idzie do przodu, ten się cofa”, jakże aktualną w dobie kryzysu.

Ostatnim, najbardziej, można by powiedzieć, tradycyjnym zadaniem instytucji wspierających przedsiębiorczość wskazanym przez autorów jest pomoc w dążeniu do zakładania własnej działalności gospodarczej. Zła sytuacja na rynku pracy paradoksalnie może być motorem do tworzenia nowych miejsc pracy przez samych zainteresowanych. Osoby przedsiębiorcze, nie znajdując zatrudnienia lub otrzymując propozycje pracy znacznie poniżej swoich kwalifikacji, mogą wybierać działalność gospodarczą jako sposób na samozatrudnienie, tworząc przy okazji nowe miejsca pracy. Zgodnie z danymi GUS, w Polsce od roku 2004 do 2010 liczba nowo rejestrowanych podmiotów gospodarczych z roku na rok zwiększała się (ryc. 2). W roku 2004 nowych podmiotów zarejestrowano poniżej 200, w latach 2006 i 2007 ich liczba utrzymywała się na poziomie 250, 
a w roku 2010 zarejestrowano ich 350 . W ostatnim roku liczba nowych podmiotów spadła do 300. Wsparcie dla otwierających nowe przedsiębiorstwa powinno być kierowane zatem po pierwsze w celu przeciwdziałania rozpoczynającej się niekorzystnej tendencji spadkowej w dynamice nowo otwieranych przedsiębiorstw, a po drugie w celu dobrego przygotowania przyszłych przedsiębiorców do działalności, co zmniejszy odsetek firm nieprzeżywających pierwszego roku działalności.

Ryc. 2. Dynamika zmiany zgłoszeń liczby nowych podmiotów gospodarczych w Polsce w latach 2003-2011

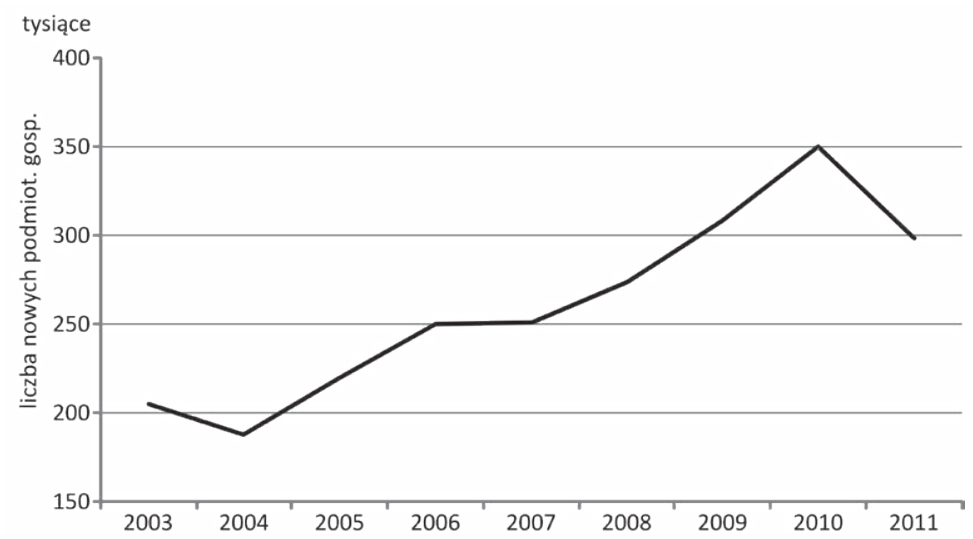

Źródło: opracowanie własne na podstawie danych GUS.

Godne uwagi jest również przestrzenne zróżnicowanie dynamiki poziomu zgłoszeń nowych podmiotów gospodarczych w Polsce w badanych latach, gdyż jest ono w porównaniu ze średnią krajową bardzo duże. Próbując wskazać prawidłowości przestrzenne, należy zauważyć, że najwyższą dynamiką zgłoszeń nowych podmiotów charakteryzują się powiaty województwa małopolskiego oraz powiaty ciągnące się południkowym pasem centralnych części województw: pomorskiego, kujawsko-pomorskiego, wielkopolskiego i dolnośląskiego (ryc. 3). Z kolei najsłabszą dynamikę wykazują w większości powiaty położone przy wschodniej granicy kraju

Ryc. 3. Dynamika zgłoszeń nowych podmiotów gospodarczych w powiatach Polski w latach 2003-2011

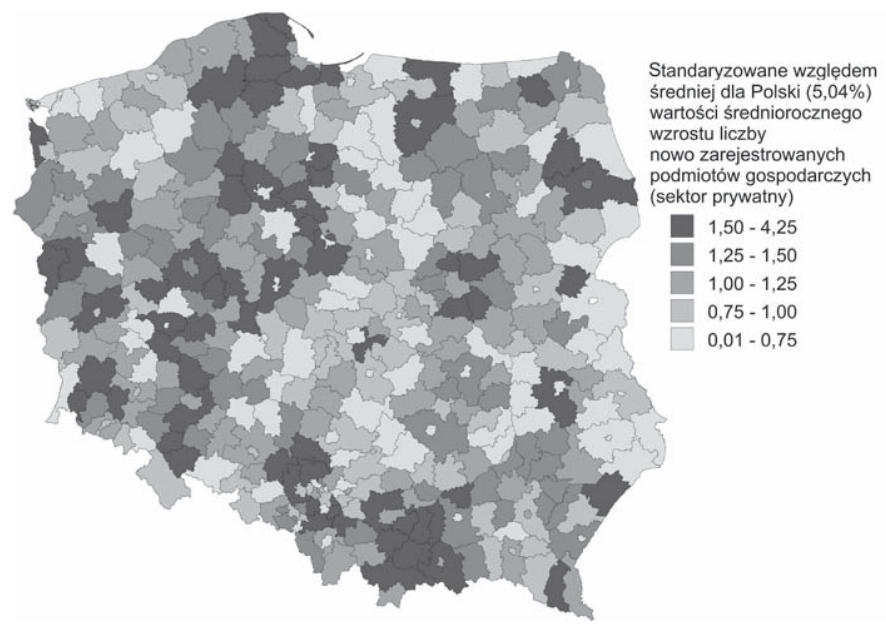

Źródło: opracowanie własne na podstawie danych GUS. 
(z wyjątkami takimi, jak powiat białostocki) oraz znów w południkowym pasie ciągnącym się zachodnimi krańcami województwa warmińsko-mazurskiego i mazowieckiego, przez województwo łódzkie, po województwo świętokrzyskie.

Abstrahując jednak od zróżnicowania przestrzennego i wracając do działań instytucji na rzecz przedsiębiorczości, należy stwierdzić, że praktyka pokazuje, że wskazane przez autorów potrzebne działania często nie są efektywne, a generalnie rzecz biorąc pomoc przedsiębiorcom w Polsce ma bardzo ograniczony charakter. Jak wynika $\mathrm{z}$ badań przeprowadzonych przez PARP $\mathrm{w}$ grudniu 2009 r., polscy przedsiębiorcy w niewielkim stopniu znają i korzystają z pomocy instytucjonalnej. Badania obejmujące próbę 1205 przedsiębiorstw wskazują, że 56\% z nich nie korzystało z żadnej zewnętrznej pomocy w czasie rozpoczynania i późniejszego prowadzenia własnej działalności. Instytucjami, z których pomocy najczęściej korzystały przedsiębiorstwa, były banki komercyjne (26\%) - zapewne głównie w zakresie udzielania pożyczek i kredytów - oraz urzędy pracy (9\%). $\mathrm{Z}$ pomocy pozostałych instytucji przedsiębiorcy korzystali w bardzo ograniczonym zakresie. Jedyne wskazane przez nich instytucje to urzędy miasta/gminy (2\%), Państwowy Fundusz Rehabilitacji Osób Niepełnosprawnych (PFRON), PARP oraz Agencja Rozwoju Regionalnego (ARR) - po 1\% (Orłowski i in., 2010). Pierwotną przyczyną tak słabego wykorzystania oferowanej pomocy jest zapewne słaba wiedza i niedocierająca do przedsiębiorców informacja o dostępnych formach pomocy. Świadczy o tym choćby badanie przeprowadzone przez MPiPS, z którego wynika przykładowo, że o najczęściej wykorzystywanej pomocy urzędów pracy, jaką jest możliwość otrzymania środków na rozpoczęcie działalności, 1/3 badanych przedsiębiorców (ubiegających się o nie) dowiedziała się od rodziny/znajomych, a zaledwie 31,9\% - z informacji dostępnych publicznie (Badanie ogólnopolskie..., 2011).

Wyniki te dały autorom powód do przeprowadzenia analizy pomocy oferowanej przez państwowe instytucje wspierania przedsiębiorczości, w której to analizie autorzy skupili się na dwóch głównych narzędziach: urzędach pracy oraz PARP. Urzędy pracy zostały wybrane do analizy jako instytucje, z których jak się okazuje, przedsiębiorcy korzystają najczęściej. Państwowa Agencja Rozwoju Przedsiębiorczości została natomiast wybrana spośród wskazywanych przez przedsiębiorców pozostałych instytucji jako narzędzie, którego głównym zadaniem jest wspieranie przedsiębiorczości (w przypadku ARR, PFRON, urzędów miasta/gminy działania te są jedynie jednymi z licznych innych działań tych instytucji i mają bardzo ograniczony zakres).

\section{Urzędy pracy}

Zakres działania urzędów pracy corocznie określany jest przez każdy wojewódzki urząd pracy w przygotowywanych planach zwanych Regionalnymi planami działania na rzecz zatrudnienia. Plany te są ogólnodostępne i publikowane na stronach internetowych urzędów, choć z przeprowadzonej przez autorów analizy wynika, że nie wszystkie urzędy dbają o częstą aktualizację danych (na stronach kilku urzędów zamieszczone były plany na 2011 r., a nie na rok bieżący). Analiza zapisów Regionalnych planów... wojewódzkich urzędów pracy na 2012 i 2011 r. (plany z 2011 r. brano pod uwagę, gdy nie było dokonanej aktualizacji) pokazuje, że każdy wojewódzki UP zakłada podjęcie działań na rzecz wspierania przedsiębiorczości, jednak zakres pomocy urzędów w planach określony jest z bardzo zróżnicowanym stopniem szczegółowości. W niektórych planach wyszczególnione są konkretne działania skierowane do określonych grup odbiorców, często z zasadami realizacji, celem działania i szczegółowymi wymaganiami w stosunku do chcących zeń skorzystać. Inne plany zawierają jedynie ogólne cele działania urzędów, zapisane hasłowo. We wszystkich jednak planach, zarówno szczegółowych, jak i ogólnych, pojawiają się działania na rzecz wspierania przedsiębiorczości. 
Najczęstsze cele zawarte w planach wojewódzkich UP to:

- promowanie przedsiębiorczości w regionie,

- wsparcie osób bezrobotnych dążących do rozpoczęcia działalności gospodarczej przez środki finansowe i wsparcie szkoleniowe,

- wsparcie istniejących przedsiębiorstw w dążeniu do zwiększania liczby stałych miejsc pracy,

- włączenie działania na rzecz rozwoju innowacyjnej gospodarki przez wsparcie transferu wiedzy z instytucji naukowych do przedsiębiorstw.

Najbardziej znaczącą i najczęściej wykorzystywaną formą pomocy, jaką urzędy pracy oferują osobom chcącym rozpocząć własną działalność gospodarczą, są środki na jej rozpoczęcie pochodzące z Funduszu Pracy. Jak wynika z raportu MPiPS (Badanie ogólnopolskie..., 2011), wysokość środków przeznaczanych na ten cel w latach 2008-2010 stale rosła. W roku 2008 wynosiła ona niecałe $700000 \mathrm{zl}$, natomiast w roku 2010 już dwukrotnie więcej - blisko 1400000 zł. Wzrosła również liczba osób, które skorzystały z tej formy pomocy urzędu pracy. W roku 2008 środki otrzymało 52160 bezrobotnych, a w roku 2010 o połowę więcej - 77020 wnioskujących (ryc. 4).

Z racji dużo większego przyrostu wielkości środków w stosunku do liczby wnioskujących wzrosła również średnia wysokość środków przyznanych wnioskującemu z 13400 zł w roku 2008 do 18040 zł w roku 2010. Pomimo wskazanych wzrostów zarówno wysokości środków ogółem, jak i średnich wartości przyznawanych poszczególnym wnioskującym, są one nadal bardzo niskie. Wielkość przyznawanych środków w stosunku do potrzeb osób rozpoczynających działalność gospodarczą jest w przypadku ogromnej większości z nich bardzo nikła.

Ryc. 4. Wielkość dofinansowania ze środków Funduszu Pracy na podjęcie działalności gospodarczej przez bezrobotnych oraz liczba osób, które otrzymały dofinansowanie w latach 2008-2010

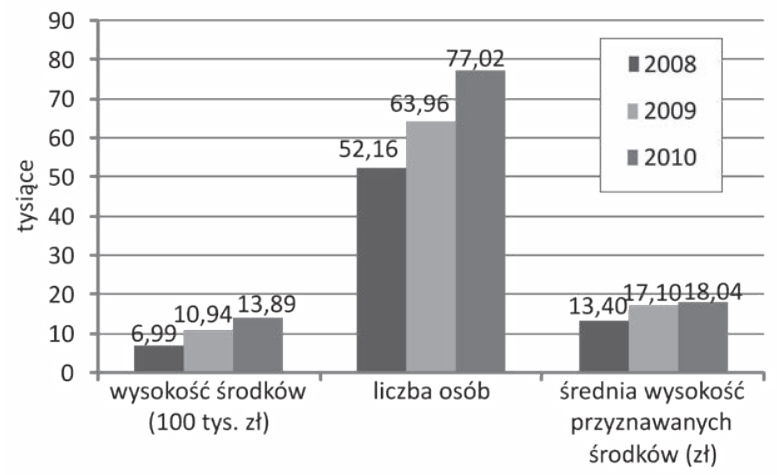

Źródło: Badanie ogólnopolskie... (2011).

Ciekawym zagadnieniem jest również przestrzenny rozkład wielkości przyznawanych środków i osób rozpoczynających działalność z pomocą Funduszu Pracy (ryc. 5). W badanych latach 2008-2011, największe nakłady na rozpoczęcie działalności przez wnioskujących przeznaczono w województwie mazowieckim (ponad 400 tys. zł). Drugie pod tym względem było województwo śląskie (ponad 350 tys. zł), a trzecie - województwo wielkopolskie (niecałe 300 tys. zł). Najmniejsze nakłady natomiast przeznaczono na ten cel w województwach lubuskim i podlaskim (niewiele ponad 90 tys. zł).

Inny rozkład przyjmują wielkości kosztów poniesionych przez urzędy pracy na rozpoczęcie jednej działalności. Wielkości te wahają się jednak nieznacznie w badanych latach od 16 do 17 tys. zł (ryc. 6). 
Ryc. 5. Środki z Funduszu Pracy przyznane bezrobotnym na założenie działalności gospodarczej w latach 2008-2011* oraz liczba osób, które uruchomiły działalność gospodarczą dzięki Funduszowi Pracy

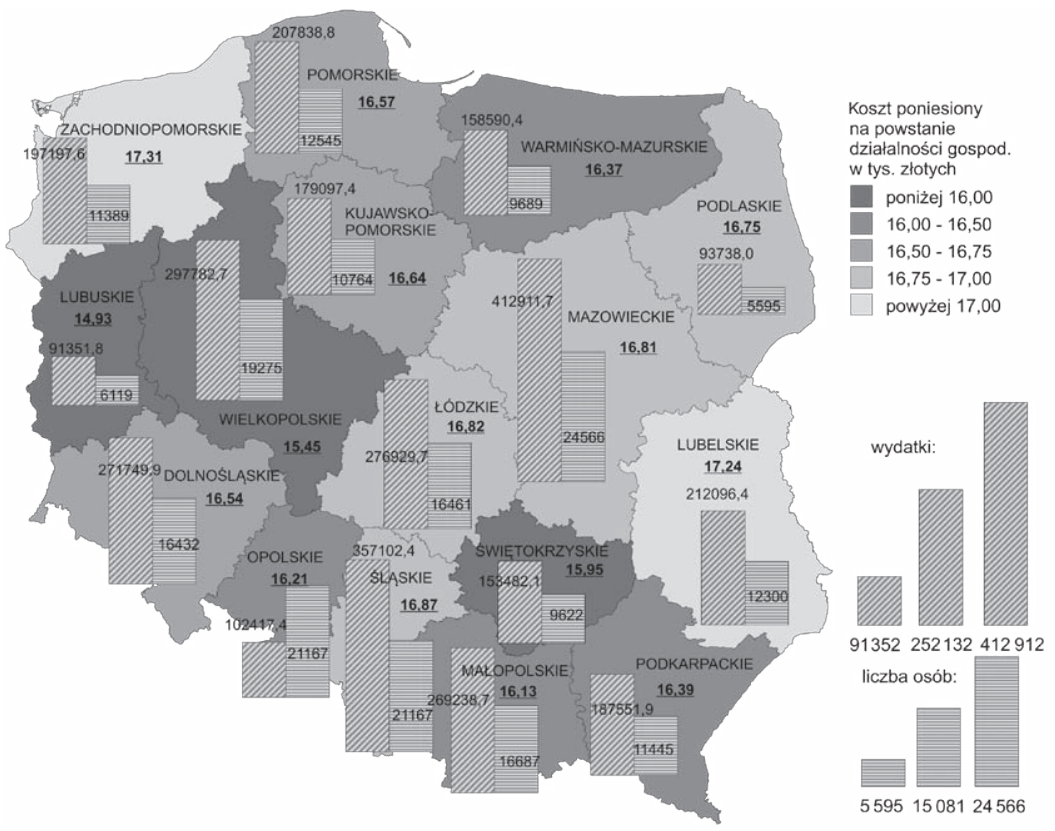

Źródło: opracowanie własne na podstawie: Badanie ogólnopolskie... (2011).

Ryc. 6. Zależność pomiędzy nakładami dla bezrobotnych z Funduszu Pracy a liczbą osób, które uruchomiły własną działalność gospodarczą dzięki Funduszowi Pracy w latach 2008-2011

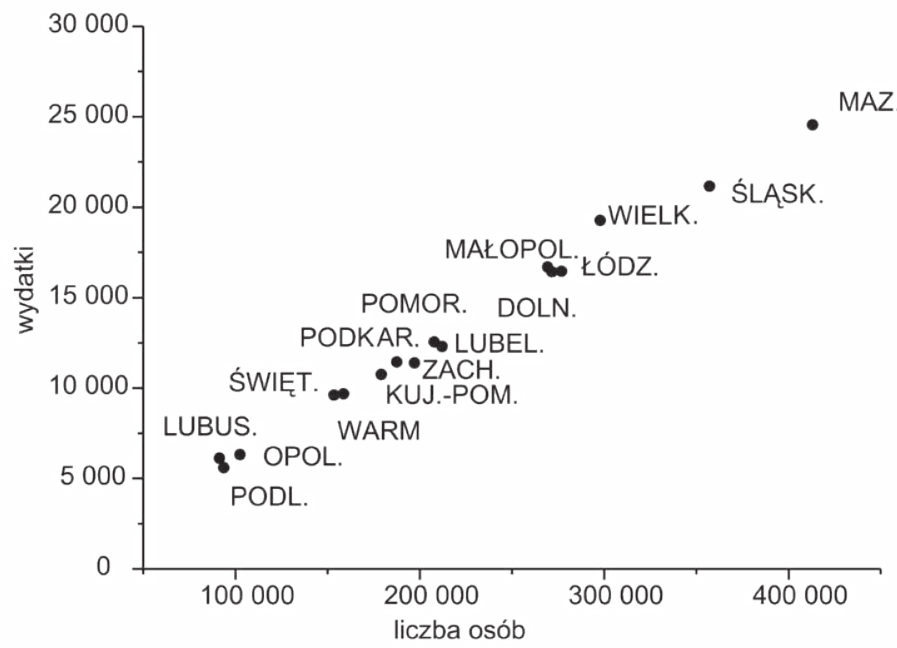

Źródło: opracowanie własne na podstawie: Badanie ogólnopolskie... (2011). 
Niemniej jednak, liczba nowych przedsiębiorców, którzy skorzystali ze środków z Funduszu Pracy wśród ogółu rozpoczynających działalność gospodarczą jest znacząca. W latach 2008-2010 największy udział wśród wszystkich nowych przedsiębiorców stanowili oni w województwie lubuskim - aż 34\%, zachodniopomorskim - 29\%, wielkopolskim - 28\%, kujawsko-pomorskim i świętokrzyskim - po 27\%. Jedynie w województwie łódzkim (16\%), podkarpackim (17\%) i warmińsko-mazurskim (19\%) stanowili poniżej 20\% nowych przedsiębiorców (ryc. 7).

Ryc. 7. Udział osób rozpoczynających działalność gospodarczą z wykorzystaniem środków z Funduszu Pracy w ogóle rozpoczynających działalność gospodarczą w latach 2008-2010

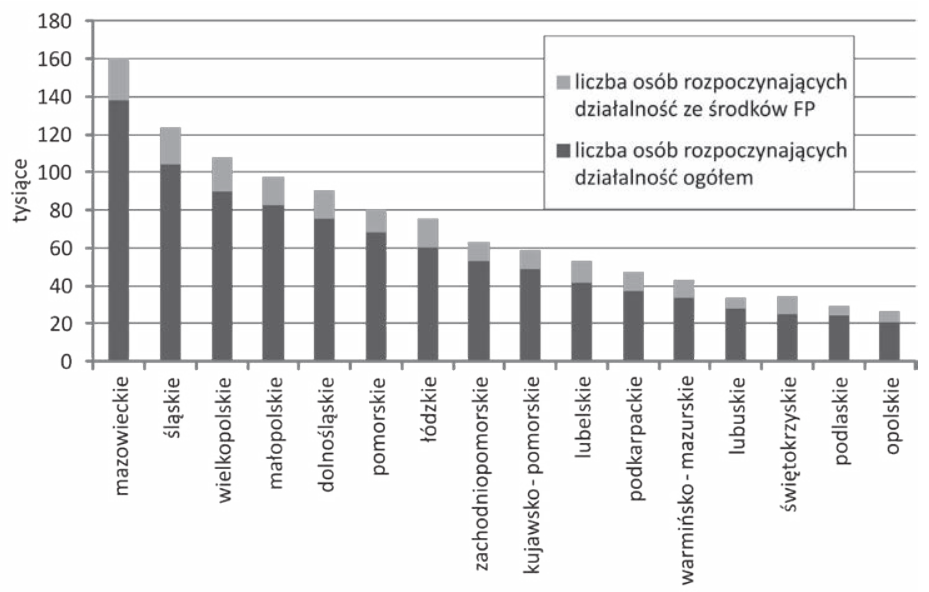

Źródło: Opracowanie własne na podstawie: Badanie ogólnopolskie... (2011).

Oprócz najpopularniejszej formy w postaci środków na rozpoczęcie działalności, ubiegający się o nie korzystają również z innych form pomocy oferowanych przez urząd pracy. Najczęściej korzystają ze szkoleń zawodowych (43,1\%), staży lub praktyk zawodowych $(21,6 \%)$, rzadziej z pośrednictwa pracy $(7,2 \%)$, porad lub doradztwa zawodowego $(6,5 \%)$ oraz warsztatów/zajęć grupowych z zakresu aktywnego poszukiwania pracy $(5,9 \%)$ (ryc. 8).

Ryc. 8. Korzystanie przez ubiegających się o dotacje na rozpoczęcie działalności z form wsparcia urzędów pracy

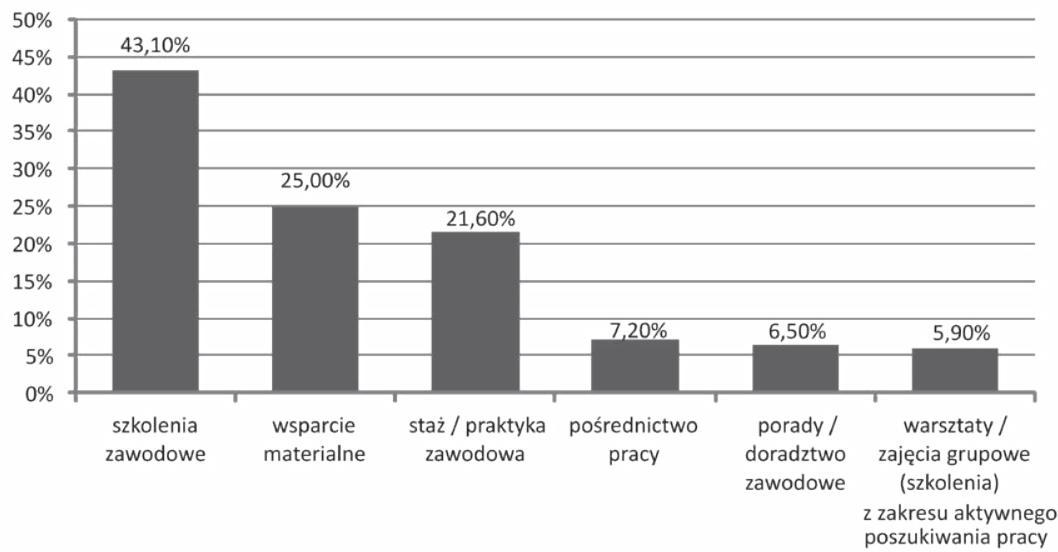

Źródło: Opracowanie własne na podstawie: Badanie ogólnopolskie... (2011). 
Najważniejszą z punktu widzenia rozpoczynających działalność jest oferta szkoleniowa. Zgodnie z wynikami badań nad zakresem tematycznym szkoleń oferowanych przez powiatowe urzędy pracy zawartych w raporcie MPiPS (Badanie ogólnopolskie..., 2011), wśród szkoleń mających tematycznie związek z zakładaniem działalności urzędy pracy najczęściej proponują szkolenia z zakresu: podstaw przedsiębiorczości $(67,6 \%)$, informacji o formalnościach związanych z rozpoczęciem i prowadzeniem działalności gospodarczej $(63,6 \%)$ oraz praktycznych porad związanych z prowadzeniem działalności gospodarczej (57,6\%). Ponad 1/3 urzędów oferuje natomiast szkolenia z zakresu: sposobu rozliczania przyznawanych środków (39\%), poprawnego przygotowania wniosków o dofinansowanie działalności gospodarczej (pod względem formalnym) (39\%), poprawnego przygotowania wniosków o dofinansowanie działalności gospodarczej (pod względem merytorycznym: analiza szans i zagrożeń, analiza rynku) (35,7\%), warunków przyznawania dofinansowań na rozpoczęcie działalności (36,2\%) (Badanie ogólnopolskie..., 2011).

Jak wynika z analizy, oferta szkoleń dla rozpoczynających działalność występuje w wielu urzędach pracy, ale nie jest ona bogata i bardzo skoncentrowana na pozyskiwaniu środków na działalność.

Warto jednak dodać, że wyniki oceny (przez badanych w 2011 r.) pomocy urzędów pracy w podjęciu decyzji o rozpoczęciu działalności gospodarczej i przygotowaniu wniosku o dofinansowanie były bardzo wysokie: średnio 4,35 (w skali 1-5) (Badanie ogólnopolskie..., 2011). Co bardzo istotne, a przemawiające również na korzyść pomocy z urzędu pracy wśród badanych przedsiębiorców, którzy rozpoczęli działalność gospodarczą z udziałem ich wsparcia finansowego w latach 2008-2011, aż 85\% osób nadal prowadzi tę działalność. „Przeżywalność” tych nowych firm jest zatem wysoka. Czy wpływ na ten wynik miały szkolenia przygotowujące przedsiębiorców do prowadzenia działalności, a prowadzone przez urzędy pracy? Niestety, nie można tego jednoznacznie stwierdzić.

Po dokonaniu analizy zapisów Regionalnych planów na rzecz zatrudnienia i zgromadzonych danych statystycznych autorzy postanowili skonfrontować zapisy i przeważający, pozytywny obraz wyłaniający się ze statystyk z rzeczywistością. W tym celu udali się do Grodzkiego Urzędu Pracy w Krakowie, by sprawdzić jego ofertę dla potencjalnych przedsiębiorców. Niestety, okazało się, że uzyskanie pomocy nie jest takie proste i wymaga spełnienia licznych warunków. Po pierwsze, jak w przypadku wszystkich urzędów pracy, by skorzystać z pomocy należy być zarejestrowanym jako osoba bezrobotna. W Krakowie, by starać się o pomoc należy mieć status bezrobotnego przez minimum miesiąc. Kierowanie pomocy do osób bezrobotnych jest zdaniem autorów działaniem mało celowym. Bezrobotni, a zatem osoby, które prawdopodobnie dłuższy czas nie mogły poradzić sobie ze znalezieniem pracy na rynku, mogą okazać się zbyt mało przedsiębiorczy, by prowadzić własną działalność gospodarczą. Poza tym wymóg bycia bezrobotnym zapewne skłania osoby do zarejestrowania się na bezrobociu tylko dla skorzystania z oferty dla przyszłych przedsiębiorców (strata czasu i pieniędzy...).

Innymi wymaganiami, które należy spełnić, aby otrzymać pomoc, to bycie zameldowanym w Krakowie oraz brak odmowy przy proponowanych dotychczas ofertach pracy (a zatem trzeba cierpliwie wytrzymać miesiąc na bezrobociu, licząc na to, że nie znajdzie się żadna praca, co jednak nie jest trudne, bo ofert nie jest zbyt dużo). Co jednak bardziej istotne, o środki może starać się bezrobotny, który nie otrzymał dotychczas środków z Funduszu Pracy oraz nie prowadził działalności gospodarczej w okresie ostatnich 12 miesięcy. Po spełnieniu wszystkich wymagań, by otrzymać pomoc i środki na rozpoczęcie działalności z krakowskiego urzędu pracy należy przejść kilka etapów, z których każdy kończy się zaopiniowaniem urzędowej komisji. Najpierw należy złożyć wniosek, a następnie pójść na szkolenie. Po jego zaliczeniu i zakwalifikowaniu się do następnego etapu, należy napisać biznesplan swojej działalności. Jest on opiniowany i na podstawie oceny komisji oraz w zależności od liczby chętnych bezrobotny ewentualnie dostaje środki na działalność, 
którą zobowiązuje się prowadzić min. 12 miesięcy (inaczej środki podlegają zwrotowi). Środki muszą być oczywiście wydatkowane zgodnie z wytycznymi urzędu (np. wg zasad krakowskiego UP można z nich pokryć maksymalnie trzy czynsze, nie wolno finansować usług świadczonych przez rodzinę itd.). Co najdziwniejsze, bezrobotny, składając wniosek, musi mieć tytuł prawny do lokalu, w którym działalność ma być prowadzona, oraz posiadać, jeśli są wymagane, niezbędne zezwolenia i koncesje. Pierwszy z wymogów sprawia, że bezrobotny powinien posiadać lokal lub np. umowę najmu lokalu. Zakładając drugi wariant, musi zawrzeć umowę z wyprzedzeniem, przed złożeniem wniosku i płacić za wynajem lokalu przez cały czas starania się o dotację, nie mając jeszcze nawet założonej działalności gospodarczej. Drugi wymóg natomiast jest wręcz absurdalny - większość zezwoleń/ koncesji uzyskuje się bowiem na konkretną działalność gospodarczą, przy czym należy spełnić szereg określonych warunków. Niech przykładem będzie choćby najbardziej popularna koncesja - na sprzedaż napojów alkoholowych. Żeby uzyskać taką koncesję, należy się o nią starać jako przedsiębiorstwo, posiadać tytuł prawny do lokalu spełniającego określone wymagania oraz pozytywny odbiór stacji sanitarno-epidemiologicznej. Jak zatem widać, jest to niemożliwe, gdy jest się osobą bezrobotną składającą wniosek do UP.

Wszystkie wymienione przeszkody w otrzymaniu pomocy z urzędu pracy tracą jednak zupełnie swoje znaczenie w obliczu informacji, jaką uzyskaliśmy w szczerych rozmowach z pracownikami krakowskiego urzędu pracy, podczas których bez ogródek poinformowali nas oni, że składanie wniosku teraz (połowa września) nie ma sensu. Okazuje się bowiem, że w jednym z największych polskich miast środki na dofinansowanie działalności w urzędzie pracy kończą się już we wrześniu, a o kolejne można starać się dopiero od stycznia.

Pozytywna ocena pomocy urzędów pracy dla rozpoczynających działalność gospodarczą wyłaniająca się z początkowych analiz statystyk, raportu MPiPS i zapisów Regionalnych planów na rzecz zatrudnienia w konfrontacji z realiami przykładowego, krakowskiego urzędu pracy zdecydowanie się zatem zmienia...

\section{Polska Agencja Rozwoju Przedsiębiorczości}

W drugiej części opracowania pochylono się nad działaniami realizowanymi przez PARP. Jest to instytucja rządowa powstała w 2000 r., której zadaniem jest zarządzanie funduszami z budżetu państwa i Unii Europejskiej, przeznaczonymi na wspieranie: przedsiębiorczości, innowacyjności i rozwoju zasobów ludzkich. Działania Agencji koncentrują się głównie na stymulowaniu i kreowaniu postaw przedsiębiorczych. Zgodnie z głoszonymi hasłami: „PARP - wspiera przedsiębiorców w realizacji ich wizji” czy „PARP - partnerem w drodze do sukcesu Twojej Firmy" celem działania agencji jest realizacja programów wspierających działalność małych i średnich przedsiębiorstw (MŚP), rozwój regionalny i zasobów ludzkich oraz wykorzystywanie i rozwój nowych technologii i innowacji.

Agencja posiada dobrze rozbudowane usługi online, co w znaczący sposób zwiększa dostępność do jej oferty. Każdy zainteresowany w czterech krokach może odnaleźć programy realizowane przez Agencję, wśród których znajdują się programy pomocne w założeniu własnej firmy. Ofertę taką można odnaleźć zarówno w ofercie skierowanej do kandydata na przedsiębiorcę, jak i przedsiębiorcy lub pracownika. Określając potrzeby, można odnaleźć pozycje: „chcę założyć firmę”, jak i ,chcę ponownie założyć”. Osobno określone są oferty z zakresu wiedzy o tym, jak założyć firmę, jak prowadzić firmę, lub skąd pozyskać środki na start. Spośród wszystkich programów oferowanych przez PARP przeanalizowano pod kątem zakładania własnej działalności gospodarczej cztery wybrane: bazę ofert szkoleniowych - Inwestycja w kadry, pomoc informacyjną i doradczą ośrodków Krajowego Systemu Usług (KSU), akademię i publikacje PARP oraz Centralną Ewidencję i Informację o Działalności Gospodarczej (CEIDG). 
Ryc. 9. Liczba szkoleń PARP w latach 2009-2012 (A) oraz ich tematyka (B)

A.

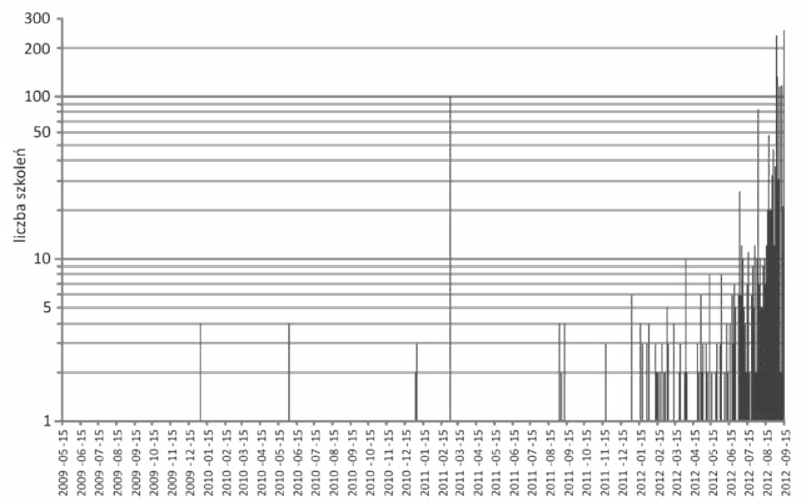

B.

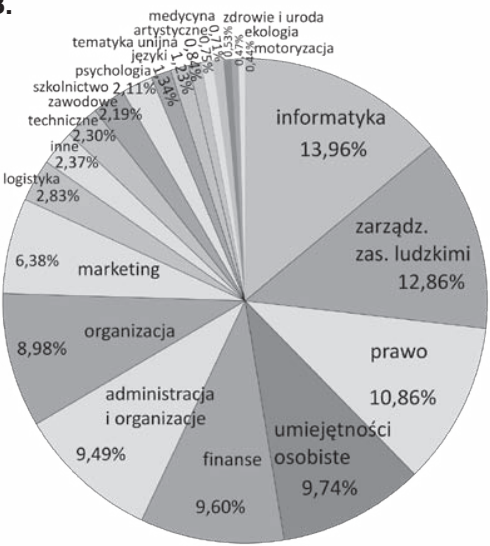

Źródło: opracowanie danych na podstawie kwerendy ofert PARP.

W pierwszej kolejności autorzy poddali analizie oferty szkoleniowe oferowane przez program „Inwestycje w kadry)”, w ramach którego przeanalizowano 1332 oferowane tematy kursów i szkoleń realizowanych na terenie całego kraju. Do 2012 szkolenia były prowadzone sporadyczne, a największe ich natężenie datuje się od połowy 2012 r. (ryc. 9A). Spośród ofert szkoleń najwięcej poświęcono informatyce i zarządzaniu zasobami ludzkimi (ryc. 9B). Brak natomiast jest propozycji odnoszących się do rozpoczynania własnej działalności gospodarczej. W układzie powiatowym szkolenia prowadzane są głównie w największych miastach. Wynika to zapewne $\mathrm{z}$ istniejącego tam zaplecza oraz dużej liczby potencjalnych klientów. Jednakże to peryferie są bardziej narażone na spowolnienie gospodarcze związane z kryzysem światowym. Dlatego wydaje się bardzo niekorzystnym brak szkoleń na północy - Warmia i Mazury oraz Pomorze Środkowe - czyli w obszarach o największej stopie bezrobocia (ryc. 10).

Ryc. 10. Lokalizacja szkoleń PARP (A) i rozmieszenie ośrodków KSU na tle stopy bezrobocia (B)

A.

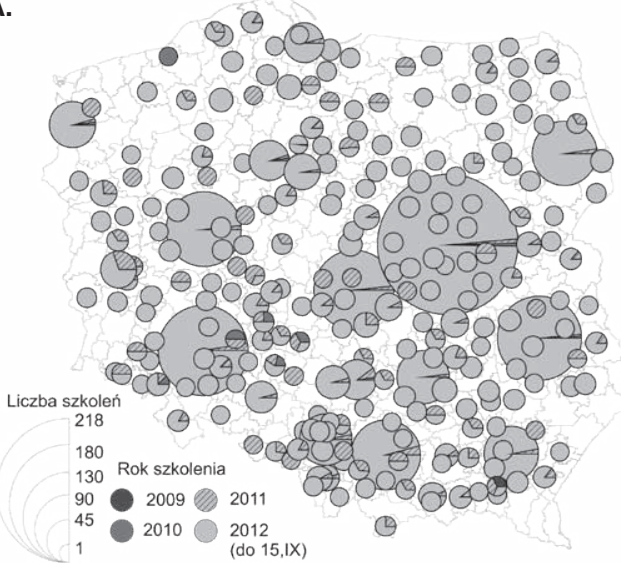

B.

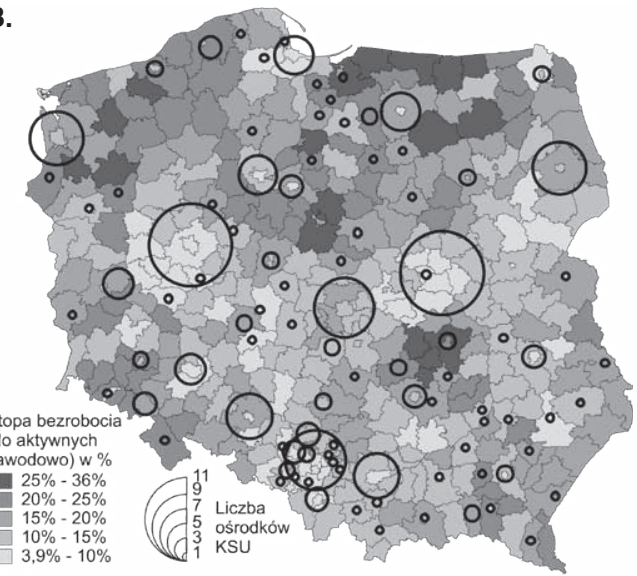

Źródło: opracowanie danych na podstawie kwerendy ofert PARP i KSU. 
Spośród 1332 szkoleń zrealizowanych i zaplanowanych do końca 2012 r. znaleziono tylko 5 szkoleń związanych z zakładaniem własnej działalności gospodarczej. Na szkoleniach tych oferowano wiedzę z zakresu zarówno procesu rejestracji działalności gospodarczej, jak i jej prowadzenia. Pomijając jednak merytoryczną stronę szkoleń, skierowane one były głównie do ściśle określonych grup ludności. Byli to bezrobotni, osoby zwalniane z pracy (branża wojskowa), osoby do 25 roku życia lub powyżej 50 roku życia oraz kobiety i niepełnosprawni. W pozostałych przypadkach szkolenia były płatne i kosztowały od 4 tys. do 5 tys. zł. Następował więc proces marginalizacji wybranych grup społecznych prowadzący do ich dyskryminacji na rynku pracy (Osuch, Dwojak, 2009). Lokalizacja szkoleń również była nierównomiernie rozmieszona na terenie Polski. Szkolenia obejmowały głównie mieszkańców powiatów na południu Polski: tarnowskiego, limanowskiego, dąbrowskiego, suskiego, gliwickiego, a także Tarnobrzegu i województwa zachodniopomorskiego. Zauważyć należy, że szkolenia skierowane były w szczególności do grup osób silnie narażonych na bezrobocie, co ograniczało w znacznym stopniu dostęp do szkoleń dla tzw. przeciętnego człowieka, również w aspekcie wydłużenia wieku emerytalnego (Kurek, Rachwał, 2011).

Poza przedstawionymi działaniami szkoleniowymi, w PARP prowadzone są także programy informacyjne i doradcze realizowane w ramach powołanego do życia w 1996 r. Krajowego Systemu Usług. System składa się z ok. 200 zarejestrowanych ośrodków, świadczących usługi wspierające polskich przedsiębiorców. Misją ośrodków jest rozwój przedsiębiorstw przez zapewnienie najwyższej jakości usług w kluczowych obszarach wymagających wsparcia państwa. W ramach KSU świadczone są usługi dla przedsiębiorców z zakresu informacji oraz doradztwa dla przedsiębiorców i osób zamierzających rozpocząć działalność gospodarczą w ramach Punktów Konsultacyjnych KSU oraz z zakresu działań proinnowacyjnych dla przedsiębiorców w ramach Krajowej Sieci Innowacji. System oferuje również usługi finansowe, takie jak udzielanie poręczeń kredytów lub pożyczek dla przedsiębiorców, oraz usługi pilotażowe w zakresie ochrony środowiska i finansowania zwrotnego dla mikro- i małych przedsiębiorców. Wśród ośrodków KSU znajdują się zarówno Punkty Konsultacyjne, jak i ośrodki Krajowej Sieci Innowacji.

Punkty Krajowego Systemu Usług zostały w dużej minerze sfinansowane ze środków unijnych w ramach projektu ,Wsparcie systemu kompleksowych usług informacyjnych dla przedsiębiorców oraz osób zamierzających rozpocząć działalność gospodarczą poprzez finansowanie sieci Punktów Konsultacyjnych (PK)”, realizowanego w okresie od września 2008 r. do kwietnia 2012 r. w ramach PO KL. Celem projektu było zapewnienie dostępności usług dla przedsiębiorców i osób zamierzających rozpocząć działalność gospodarczą. W ramach podjętych działań oferowano usługi informacyjne z zakresu szeroko rozumianego rozwoju przedsiębiorczości, w tym dostępnych form wsparcia, świadczonych przez współpracujące ze sobą instytucje w ramach Krajowego Systemu Usług. W okresie realizacji projektu PK KSU obsłużyły 188568 klientów i zrealizowały 218541 usług.

Analizując rozmieszenie podmiotów KSU, można zauważyć, że punkty konsultacyjne i ośrodki zlokalizowane są na obszarze niemal całej Polski z niewielką przewagą części południowej (ryc. 11A). Jednakże wydaje się, że podobnie jak w przypadku miejsca prowadzonych szkoleń PARP, pominięte zostały regiony północno-wschodnie kraju i środkowe - Pomorza, czyli regiony najbardziej zagrożone bezrobociem, posiadające najniższy współczynnik aktywności ekonomicznej (Makieła, 2007), w których to takie działania wydają się jak najbardziej pożądane (Rachwał, 2010). 
Ryc. 11. Lokalizacja Punktów Konsultacyjnych KSU (A) i udział usług biznesowych dostępnych dla osób rozpoczynających działalność gospodarczą dostępnych w poszczególnych województwach w 2012 r. (B)

A.

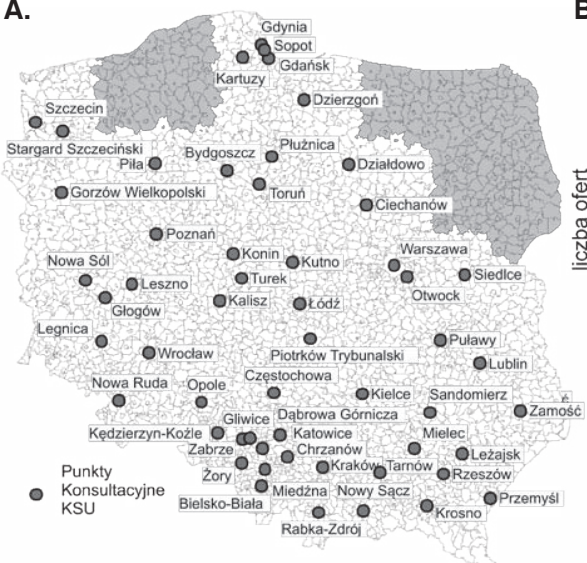

B.

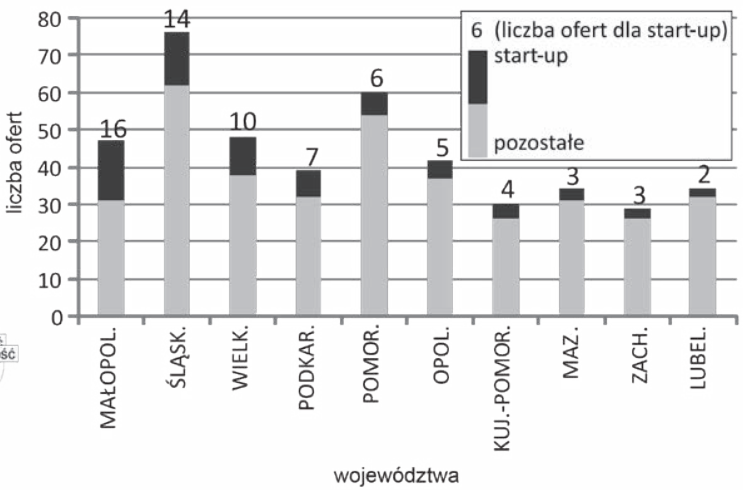

Źródło: opracowanie danych na podstawie kwerendy ofert KSU.

Spośród ofert systemu najbardziej przydatny dla osób planujących założyć własną działalność gospodarczą jest program „Wsparcie dla nowych firm”. Ta bezpłatna oferta realizowana jest przez 330 konsultantów w 51 Punktach Konsultacyjnych KSU i skierowana jest do początkujących przedsiębiorców. Wśród ofert KSU można znaleźć m.in. to, jak krok po kroku założyć własną firmę, dobierając jej optymalną formę prawną oraz rodzaj opodatkowania; jakie dokumenty są niezbędne do rejestracji działalności gospodarczej i jak je przygotować; jakie czekają przedsiębiorcę obowiązki rejestracyjne: w organie rejestrującym - ewidencja działalności w gminie lub Krajowym Rejestrze Sądowym (KRS) - na potrzeby ubezpieczeń społecznych, dla celów statystycznych i innych; jaki jest orientacyjny czas potrzebny na założenie firmy; jakie czekają opłaty związane z rejestracją firmy itp.; skąd i w jaki sposób pozyskać środki finansowe na założenie i rozwój firmy oraz jak pokonywać problemy pojawiające się w bieżącej działalności przedsiębiorstwa. Obok powyższych bezpłatnych ofert informacyjnych, KSU oferują płatną usługę doradczą w cenie 160 zł (90\% refunduje państwo) z zakresu konsultacji profilu planowanej działalności gospodarczej lub pomocy w przygotowaniu biznesplanu i zgromadzeniu niezbędnej dokumentacji. Można również skorzystać z płatnej asysty w prowadzeniu działalności gospodarczej (cena 240 zł) z zakresu formalno-prawnych obowiązków związanych z prowadzeniem firmy; marketingu przedsiębiorstwa; organizacji firmy lub korzystania ze źródeł finansowania dedykowanych przedsiębiorcom. Spośród oferowanych usług w $2012 \mathrm{r}$. oferty skierowane do start-upów stanowiły nie więcej niż $25 \%$ ogółu propozycji, przy czym najwięcej ofert było w Małopolsce i na Śląsku (ryc. 11B)

Następna poddana analizie usługa to Centralna Ewidencja i Informacja o Działalności Gospodarczej. Jest to działający od 2011 r. portal ułatwiający założenie działalności gospodarczej (oraz jej zawieszenie, zakończenie lub wznowienie) zdalnie przy pomocy komputera. Portal zawiera wszystkie potrzebne formularze i instrukcje oraz materiały szkoleniowe. Usługa ta nie wpływa bezpośrednio na proces zakładania firm, tak jak w przypadku dotacji i zachęt finansowych (choć te działania spotykają się z krytyką ze względu na ich nieetyczność, tj. przekazywanie publicznych pieniędzy; Dziewulski, 2009), jednakże usługa ta usprawnia sam proces biurokratyczny (Wach, 2005). 
Analizując liczbę zakładanych firm w latach 1992-2012 (wrzesień), widać ciągły wzrost z gwałtownym skokiem w 2001 r. oraz spadkiem w 2011 r. (ryc. 12A). Analizując z kolei wykorzystanie możliwości działań online, widać, że systematycznie wzrasta wykorzystanie portalu. Gwałtowny wzrost obserwujemy po roku 2012, od kiedy to portal nie jest wykorzystywany jedynie do zakładania firm, lecz również do działań mających na celu zakończenie lub zawieszenie działalności (ryc. 12B). Działania te przekładają się na większe możliwości reagowania na zmieniające się warunki gospodarcze oraz ułatwiają dostęp dla regionów peryferyjnych. W analizie rozkładu aktywności na portalu można zwrócić uwagę na cykliczne przerwy związane z brakiem lub obniżeniem działań na portalu. W przeważającej większości są to weekendy i święta. W ujęciu tym wydaje się ciekawe, że najdłuższy zastój obserwujemy w tzw. weekendzie majowym, kiedy to na prawie tydzień ustają wszelkie działania administracyjne.

Ryc. 12. Zgłoszenia działalności gospodarczej w latach 1992-2012 (A) oraz wnioski zgłaszane przez CEIDG w III i IV kwartale 2011 oraz I i II kwartale 2012

A.

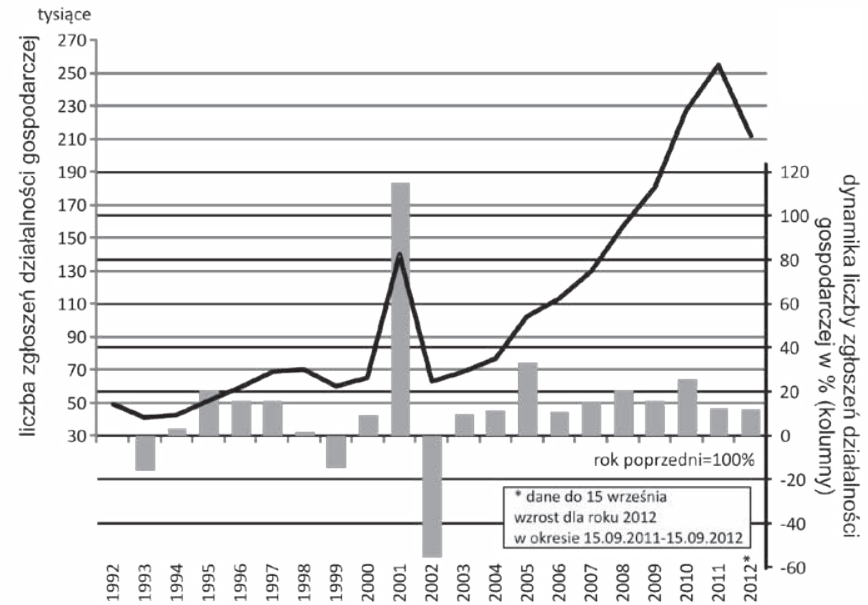

B.

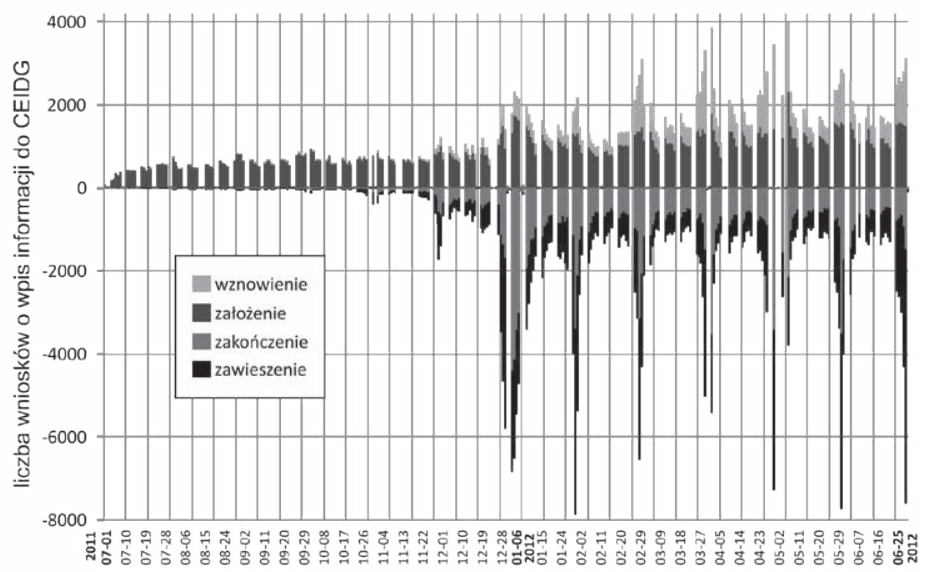

Źródło: opracowanie własne na podstawie GUS i CEIDG. 
Ostatnią analizowaną usługą jest Akademia PARP. Jest to portal edukacyjny dla małych i średnich przedsiębiorstw z systemem bezpłatnych szkoleń internetowych. Inauguracja portalu i projektu odbyła się w 2006 r szkoleniem e-learningowym nt. zarządzania strategicznego „Jak rozwijać firmę? Systemy zarządzania dla MMŚP”. Celem Akademii jest darmowe upowszechnienie dostępu do wiedzy biznesowej za pomocą metod zdalnej edukacji wśród: uczestników z mikro-, małych i średnich przedsiębiorstw, ograniczonej liczby uczestników z dużych przedsiębiorstw oraz osób planujących założenie własnej działalności gospodarczej. W ramach szkoleń uczestnicy mogą korzystać ze wsparcia infolinii z opiekunami kontaktującymi się telefonicznie lub przez e-mail, przez 12 godzin dziennie, przez 6 dni w tygodniu. Dodatkową możliwością jest dostęp do ekspertów merytorycznych - tutorów. Dokonując przeglądu oferowanych szkoleń pod kątem rozwijania własnej działalności gospodarczej, wyróżniono następujące szkolenie: „Jak założyć własną firmę” - składające się z 7 modułów omawiających nie tylko zagadnienia praktyczne, ale też teoretyczne. Godne uwagi są zamieszczone na stronach portalu testy, w tym test diagnozujący wiedzę.

Poza ciągłymi działaniami w PARP podejmowane są też specjalne działania na rzecz rozwoju własnej działalności. Przykładem mogą być uruchomione w zeszłym roku programy: start-up oraz techno starter, realizowane w ramach programu: „2011 - rokiem nowo powstałych firm”.

Start-up to nowy podmiot gospodarczy w początkowym okresie funkcjonowania lub przedsiębiorstwo, które rozpoczęło działalność i jest w pierwszej fazie rozwoju, niezależnie od jego wielkości. Najczęściej jednak jest to mikro- bądź małe przedsiębiorstwo, które nie sprzedaje jeszcze swoich produktów komercyjnie, lecz rozwija produkt i kompletuje dane marketingowe. Według badań PARP, corocznie publikowanych w Raporcie o stanie sektora MŚP, żywotność start-upów (firm działających poniżej 1 roku) wynosi 76,4\%. Natomiast technostarter (technology start-up) to przedsiębiorstwo założone przez pracownika lub pracowników środowisk naukowych wykorzystujących innowacyjne rozwiązania, do których posiadają prawa. Technostarterzy są najczęściej związani z uczelniami kapitałowo lub operacyjnie (spin-out) lub nie (spin-off). Instytucjami wspierającymi są parki oraz inkubatory technologiczne.

\section{Zakończenie}

Podsumowując przedstawione powyżej działania wybranych instytucji publicznych na rzecz wsparcia przedsiębiorczości w Polsce w dobie kryzysu gospodarczego, należy stwierdzić, że instytucje publiczne oferują szeroką gamę pomocy i usług związanych z założeniem własnej działalności gospodarczej. Jednakże to, co jest zauważalne, to małe wykorzystanie tych ofert, spowodowane bądź to brakiem informacji, bądź brakiem zainteresowania ze strony potencjalnych odbiorców tych usług. Inną zauważalną cechą w oferowanej pomocy publicznej jest ograniczony dostęp do niej. Ograniczenia te mają podłoże przestrzenne związane głównie z dyskryminacją peryferyjnych regionów Polski. Innym przejawem ograniczeń są uwarunkowania finansowe, które ograniczają możliwości pomocy wszystkim zainteresowanym. Dodatkowo uwidacznia się bardzo wyraźnie cenzus związany z wymogami stawianymi przed odbiorcami usług publicznych. Oferty kierowane są zazwyczaj do ludzi bezrobotnych, kobiet, osób młodych lub starszych. Również preferowane są różne branże zawodowe, np. wojskowi. Uwarunkowania te doprowadzają do patologii związanych np. z fałszowaniem swojej pozycji zawodowej (przejście na bezrobocie w związku z oczekiwaniem większej pomocy ze strony państwa). Wydaje się zatem właściwe podejmowanie większej liczby działań oraz ich promocji zwłaszcza wśród grup kreatywnych. Większa aktywizacja ludzi przedsiębiorczych może okazać się lepszym narzędziem walki z bezrobociem niż finansowanie wszystkich osób spełniających pewne odgórne kryteria. Zdaniem autorów, lepszymi adresatami omawianych usług oferowanych przez urzędy pracy i PARP byliby 
choćby mało doświadczeni, ale za to zdeterminowani do założenia własnej działalności gospodarczej (i przez to samozatrudnienia) absolwenci uczelni wyższych, lecz również szkół średnich.

Spośród wskazanych działań na pewno na uwagę zasługują działania innowacyjne, w tym głównie wykorzystanie technik ICT w procesie szkoleń i zakładania własnej działalności. $\mathrm{Z}$ jednej strony ułatwiają one pewne działania, a z drugiej strony je uatrakcyjniają, co również wydaje się godne pochwały. Pewien niedosyt można odczuć w związku z liczbą oferowanych szkoleń w terenie, gdzie większy nacisk powinien zostać położony na pomoc przy planowaniu i rozpoczęciu własnej działalności gospodarczej. To właśnie obawy związane z brakiem wiedzy z zakresu zakładania firmy oraz brak pomocy w tym temacie wydają się główną barierą rozwoju samozatrudnienia. Wzorem innych krajów wydaje się, że takie działania niekoniecznie muszą być realizowane przez urzędników państwowych, ale że właściwe jest wykorzystanie osób, które nabyły doświadczenie w praktyce.

\section{Literatura}

Batorska, U. (2005). Rodzaje i struktura bezrobocia w Polsce. Przedsiębiorczość - Edukacja, 1, 239-250.

Berger, S., Canning, R., Dolan, M., Kurek, S., Pilz, M., Rachwał, T. (2012). Curriculum-making in pre-vocational education in the lower secondary school: A regional comparative analysis within Europe. Journal of Curriculum Studies, 44(5), 679-701.

Dąbrowski, K. (2010). Przedsiębiorczość i edukacja jako strategie profesjonalistów na czas kryzysu. Przedsiębiorczość - Edukacja, 6, 493-498.

Dorocki, S. (2011). Wpływ kryzysu gospodarczego na przemiany struktur regionalnych Francji. Prace Komisji Geografii Przemystu Polskiego Towarzystwa Geograficznego, 17, 67-86.

Dziewulski, J. (2009). Liberalizm i keynesizm wobec kryzysu. Studia Ekonomiczne, 9, 2 (42), 25-50.

Kurek, S., Rachwał, T. (2011). Development of entrepreneurship in ageing populations of The European Union. Procedia - Social and Behavioral Sciences, 19, 397-405.

Makieła, Z. (2007). Przedsiębiorczość w Polsce w układzie regionalnym. Przedsiębiorczość - Edukacja, $3,18-23$.

MPiPS, (2011). Badanie ogólnopolskie nt. stosowanej formy aktywizacji zawodowej bezrobotnych, jaka jest przyznawanie środków Funduszu Pracy na podjęcie działalności gospodarczej. Gdańsk: EU-Consult Sp. z o.o.

Orłowski, W., Pasternak, R., Flaht, K., Szubert, D. (2010). Procesy inwestycyjne i strategie przedsiębiorstw w czasach kryzysu. Warszawa: Polska Agencja Rozwoju Przedsiębiorczości.

Osuch, W., Dwojak, A. (2009). Wspieranie przedsiębiorczości przez przeciwdziałanie marginalizacji społeczno-ekonomicznej grup nieprzystosowanych do konkurencji w gospodarce rynkowej jako dążenie do zrównoważonego rozwoju społeczeństwa informacyjnego (na przykładzie mniejszości ...). Przedsiębiorczość - Edukacja, 5, 244-253.

Piróg, D. (2012). Aspiracje i plany zawodowe młodzieży akademickiej w Polsce na przykładzie studentów geografii. W: A. Dudak, K. Klimkowska, A. Różański (red.), Przygotowanie zawodowe młodych pedagogów. Kraków: Oficyna Wydawnicza „Impuls”, 125-144.

Rachwał, T., (2010). Chapter 9. Entrepreneurship Education as a Growth Stimulus for Family Firms. W: A. Surdej, K. Wach (eds), Exploring the Dynamics of Entrepreneurship, Toruń: A. Marszałek Publishing House, 139-156.

Wach K., 2005, Wspótpraca matych i średnich przedsiębiorstw z ośrodkami naukowo-badawczymi na przykładzie Krakowskiego Parku Technologicznego. Zeszyty Naukowe Akademii Ekonomicznej w Krakowie, No. 671, s. 117-133.

Zioło, Z. (2007). Rola przedsiębiorczości w aktywizacji gospodarczej - zarys modelu. Przedsiębiorczość - Edukacja, 3, 10-17. 
Sławomir Dorocki, dr, Uniwersytet Pedagogiczny w Krakowie, Instytut Geografii, Zakład Przedsiębiorczości i Gospodarki Przestrzennej.

Absolwent studiów z zakresu geografii społeczno-ekonomicznej Uniwersytetu Pedagogicznego w Krakowie, doktor nauk humanistycznych w dyscyplinie historia (Instytut Europeistyki - Uniwersytet Jagielloński). Adiunkt w Instytucie Geografii Uniwersytetu Pedagogicznego w Krakowie. Jego zainteresowania badawcze skupiają się wokół problematyki regionów i procesów regionalizacji społeczno-gospodarczej, ze szczególnym uwzględnieniem zróżnicowania przestrzeni europejskiej oraz procesów integracji europejskiej i uwarunkowań historycznych.

Sławomir Dorocki, PhD, Pedagogical University of Cracow, Institute of Geography, Department of Entrepreneurship and Spatial Management.

Sławomir Dorocki, graduated from the Pedagogical University in Cracow, with an MA in geography, and a $\mathrm{PhD}$ in history at the Jagiellonian University (Institute of European Studies). Adiunkt (assoc. professor) at the Pedagogical University in Cracow, Institute of Geography. Research interests include regional problems and processes of socio-economic regionalization, with particular emphasis on the diversity of Europe, processes of European integration and historical conditions.

Agnieszka Świętek, mgr, Uniwersytet Pedagogiczny w Krakowie, Instytut Geografii, Zakład Przedsiębiorczości i Gospodarki Przestrzennej.

Absolwentka studiów z zakresu geografii, specjalności z przedsiębiorczością i gospodarką przestrzenną Uniwersytetu Pedagogicznego w Krakowie, gdzie pracuje jako asystent. Od 2010 r. prowadzi własną działalność gospodarczą. Jej zainteresowania badawcze skupiają się wokół zagadnień: edukacji (jako warunku poprawy poziomu życia grup zagrożonych wykluczeniem społecznym) oraz przedsiębiorczości (w szczególności przygotowania i sytuacji młodych ludzi w momencie wejścia na rynek pracy, wsparcia przedsiębiorców rozpoczynających działalność).

Agnieszka Świętek, MA, Pedagogical University of Cracow, Institute of Geography, Department of Entrepreneurship and Spatial Management.

Agnieszka Świętek, graduated from Pedagogical University in Cracow, with an MA in geography, specialized in Enterprise and land use. Asystent (assistant) at the Pedagogical University in Cracow, Institute of Geography. The author has also managed her own business since 2010. Her research interests are connected with education (as a condition of improving the standard of living of disadvantaged groups) and business (in particular, the preparation and situation of young people entering the labour market, and support to start-up companies).

Adres/Address: $\quad$ Uniwersytet Pedagogiczny w Krakowie Instytut Geografii, Zakład Przedsiębiorczości i Gospodarki Przestrzennej ul. Podchorążych 2, 30-084 Kraków, Polska e-mail: swietekaga@wp.pl,sdorocki@up.krakow.pl 